\title{
NAS CERCANIAS DA BELÉM OITOCENTISTA: ENTRE FAZENDAS, SÍTIOS, OLARIAS E ENGENHOS
}

\author{
Francivaldo Alves NUNES ${ }^{1}$
}

\begin{abstract}
Resumo: Este texto analisa os principais aspectos que constituem as propriedades rurais observadas nas cercanias da cidade de Belém no século XIX. Para isso, partimos de um processo de medição e demarcação de terras em que o requerente, o capitão da reserva e agregado do $1^{\circ}$ Batalhão de Infantaria da Guarda Nacional, Eleutério Maximiano Terra, ao justificar o deferimento de seu pedido, aponta indícios de como proprietários e agentes públicos compreendem as terras que cercam a parte mais urbanizada da capital do Pará. Assim, o estudo se propõe a compreender, a partir de relatos de viajantes, naturalistas, políticos e intelectuais, aspectos de uma cidade mergulhada em uma experiência de vida campestre que engloba as mais diversas práticas, como fazendeiros, oleiros, sitiantes, lavradores e criadores.
\end{abstract}

Palavras-Chave: Cercanias; Belém; Século XIX.

\begin{abstract}
This paper examines the main aspects that make up rural properties observed in the vicinity of the town of Belém in the nineteenth century. For this, we start from a land measurement and demarcation process in which the applicant, the captain of the reserve and added the $1^{\circ}$ Infantry Battalion of the National Guard, Eleuterio Maximiano Terra, to justify the acceptance of your order, indicate evidence of how owners and public officials understand the land surrounding the most urbanized part of the capital of Pará. Thus, the study aims to understand from reports of travelers, naturalists, politicians and intellectuals, aspects of a city steeped in a lifetime experience country encompassing the most diverse practices such as farmers, potters, ranchers, farmers and breeders.
\end{abstract}

Keywords: Outskirts; Belem; Nineteenth century.

Resumen: Este texto analiza los principales aspectos que constituyen las propiedades rurales observadas en las cercanías de la ciudad de Belém en el siglo XIX. Para ello, partimos de un proceso de medición y demarcación de tierras en que el solicitante, el capitán de la reserva y agregado del $1^{\circ}$ Batallón de Infantería de la Guardia Nacional, Eleuterio Maximiano Tierra, al justificar la aceptación de su pedido, apunta indicios de como propietarios y los agentes públicos comprenden las tierras que rodean la parte más urbanizada de la capital de Pará. Así, el estudio se propone a comprender, a partir de relatos de viajeros, naturalistas, políticos e intelectuales, aspectos de una ciudad sumida en una experiencia de vida campestre que engloba las más diversas prácticas, como hacendados, alfareros, sitiantes, labradores y criadores.

Palabras clave: Cercanías; Belén; Siglo XIX.

\footnotetext{
${ }^{1}$ Universidade Federal do Pará. E-mail: francivaldonunes@yahoo.com.br
} 
Na manhã de 14 de junho de 1877 atracava no porto de Belém, capital da província do Pará, a embarcação que trazia o senhor Eleutério Maximiano Terra. Tratava-se do capitão da reserva e agregado do $1^{\circ}$ Batalhão de Infantaria da Guarda Nacional de Belém do Pará, dono de terras na comarca da capital e com residência em Belém. Sua tarefa naquela manhã era fazer o registro de uma posse de terra, de aproximadamente meia légua quadrada, pouco mais de seis quilômetros quadrados, localizada na margem esquerda do igarapé Patanateua, freguesia de Inhangapí, de nome "Retiro da Saudade". Para isso procurou se dirigir ao juiz comissário de terras, João dos Passos Damasceno, que o atendeu prontamente lavrando o auto de medição e demarcação de terras. ${ }^{2}$ Dava-se inicio, assim, ao processo, que se tudo ocorresse conforme interesses do solicitante tinha como desfecho a autorização para emissão de titulo de proprietário, como instrumento de reconhecimento legal de suas terras. As justificativas para a solicitação de abertura de processo de medição e demarcação são bastante significativas, principalmente porque nos ajudam a entender como estes proprietários e agentes públicos compreendem as suas terras, a comarca e a própria cidade de Belém.

A primeira justificativa de Eleutério Terra nos parece bastante reveladora. Alegava que embora suas terras estivessem distantes da área mais ocupada da cidade, compreendia que como "proprietário oficialmente reconhecido" podia desprender maiores investimentos em suas posses sem o risco de serem questionadas por aventureiro que buscava "na força e na marra" se apropriar de terras, principalmente as próximas de Belém ou que fazia uma ligação com o mercado da capital através de rios e igarapé. A tranqüilidade da "posse documentada" lhe permitiria ampliar os investimentos em suas terras e conseqüentemente aumentar a produção e as rendas. Conclui seu raciocínio informando que sua propriedade podia se tornar ainda mais útil à cidade, pois permitiria que novos produtos agrícolas e de extração pudessem chegar ao mercado de Belém com maior qualidade e quantidade, assegurando maior abastecimento no mercado da capital.

Em outras palavras, o capitão da reserva e agregado do $1^{\circ}$ Batalhão de Infantaria da Guarda Nacional de Belém registrava que o reconhecimento como proprietário a ser oferecido pela administração pública era uma forma indireta em que um bom governo provincial encontrava para estender seus benefícios para as cercanias do núcleo urbano de Belém. Isto se explicaria, pois, a segurança jurídica do agora legítimo dono da terra, permitiria maior

\footnotetext{
${ }^{2}$ ITERPA. Auto de Medição e Demarcação de Terras do requerente Eleutério Maximiano Terra. Processo $\mathrm{n}^{\circ}$ 000001/1877 de 14 de junho de 1877, folhas 0001-0096.
} 
tranqüilidade para investimentos na promoção do aumento das atividades produtivas, o que assegurava um quantitativo maior de produtos a ser comercializados no mercado da capital da província por parte dos fazendeiros, sitiantes e plantadores que ocupavam as cercanias da cidade.

No processo, os fiscais do juízo comissário Avelino Pedro Manga e Gregório Franco Lameira, enviados para identificar as características do que era produzido na propriedade de Eleutério Terra, registram a presença de plantações de café, tabaco, milho, arroz e mandioca, em grande parte das áreas cultiváveis. Registravam ainda um número significativo de árvores frutíferas de diferentes espécies, sendo que parte servia para alimentação da família, dos escravos e maior quantidade era enviada para o comércio em Belém. Sem falar que se tratava de uma área possuidora de madeiras como maçaranduba e a pau d'arco, muito bem aceitas no mercado da capital, o que comprovava a ligação do que se produzia nestas terras com o comércio da capital.

As justificativas de Eleutério Terra ao apontar para um comportamento solidário com os demais proprietários da região, embora se constitua como estratégia de defesa da legalização de suas posses, nos permitem identificar um espaço dinâmico de produção que cerca a área mais urbanizada da cidade de Belém. Pelas formas de produção, estas cercanias estão caracterizadas por atividades rurais como o plantio e a criação. Vinculado pela atividade mercantil, este espaço será analisado compartilhando as reflexões que pensam os arredores dos centros urbanos em uma relação dialógica e complexa com a própria cidade, de forma a serem compreendidos como locais de produção, criação, moradia e trabalho (MARTINS, 2002, p. 15).

\section{ENTRE FAZENDAS, SÍTIOS, OLARIAS E ENGENHOS}

Embora seja difícil determinar a superfície e os limites da área de Belém no século XIX, pelo menos na primeira metade do século e alguns anos posteriores, a fala de Eleutério Terra registra uma distribuição de espaços que marcam a presença de duas paisagens que formam esta cidade. No caso, um espaço mais urbanizado marcado por moradias, casas de comércio e construções públicas, e outro nas suas cercanias em que predomina a presença de pequenas e médias propriedades que desenvolvem o plantio e a criação de animais. No entanto, como registramos, são espaços que devem ser vistos de forma conectados, embora resguardem experiências historicamente variadas. Apresentam modos de vida diferentes, mas 
que são compreendidos de maneira relacional. No caso da vida mais afastada do núcleo urbanizado, e que ganham aspectos campestres, esta deve ser analisada em termos de sentidos e de atividades, no espaço e no tempo. São locais que revelam significados que mudam, tanto em si mesmo, quanto em relação a outros espaços (WILLIAMS, 2011, p. 12).

Fundada no século XVII, desde o ano de 1751 era capital e residência do governador e capitão geral do Estado do Maranhão e Grão Pará, informa Ernesto Cruz (1973, p. 243), em clássico estudo sobre a História de Belém. Naquele século, o espaço urbano estava dividido administrativamente em duas áreas: a freguesia da Sé, que compreendia, o que poderíamos chamar hoje de bairro da Cidade Velha, onde concentraram as primeiras ruas, edificações religiosas e administrativas, e a freguesia de Sant'Anna, na qual se encontrava o atual bairro da Campina. De acordo com os estudos de Cristina Cancela (2011, p. 28), no século XIX, com o processo de crescimento do núcleo urbano, instalava-se a freguesia da Santíssima Trindade e consolidavam-se as estradas, ruas e travessas surgidas a partir do arraial de Nazaré, formando uma terceira freguesia.

Registros de aspectos mais específicos e de pormenores, não tão menos importante da cidade, são encontrados na literatura produzida por viajantes e naturalistas que visitaram a cidade de Belém na primeira metade do século XIX. De acordo com o missionário metodista Daniel Kidder (1983, p. 183-187), que esteve em Belém em 1839, a parte mais urbanizada da cidade estava formada por moradias simples e com poucas ruas em calçamento, com traçados onde faltava regularidade e bom gosto. Observava a presença de três praças públicas: a do Palácio, a do Quartel e largo da Pólvora. No entanto, apresentavam aspectos comuns aos núcleos urbanos no Brasil, um movimentado porto em que se percebia o carregamento de castanhas do Pará, cacau, baunilha, urucu, salsaparrilha, canela, tapioca, bálsamo de copaíba em boiões, peixe seco em pacotes, cestas de frutas secas e verdes, que em grande parte é resultante da produção indígena da província e de terras próximas a capital. Registra ainda um vaivém de pessoas que circulavam em busca de serviços e que oferecem produtos, principalmente nas primeiras horas da manhã.

Em comparações com outras cidades ao Norte do Império do Brasil era comum a afirmação de que as construções de Belém eram menores e mais singelas do que as de São Luís, no Maranhão, por exemplo, o que nem por isso se tratava de uma capital não próspera, destacava o naturalista Johann Baptist von Spix e o botânico Carl Friedrich Philipp von Martius no final da década de 1820 . Informava que a cidade era portadora de uma concorrida 
alfândega, que recebia mercadorias de toda a região amazônica, posteriormente encaminhadas aos portos da Europa e Estados Unidos, mas que tinha nos arredores da capital um conjunto de pequenas propriedades, que não apenas auxiliavam no abastecimento do comércio local, como podia gerar rendas com a exportação de seus produtos (SPIX \& MARTIUS, 1978, p. 27).

Os dados quantitativos de habitantes da cidade variavam a cada registro. Em 1848 o naturalista Alfred Wallace (1939, p. 17) apontava 15.000 pessoas, sendo que 1859 o médico Robert Ave-Lallemant (1980, p. 20) indicava 25.000. Com uma visão mais positiva sobre a cidade, Ave-Lallemant (1980, p. 31)destaca a presença de belas casas e palácios em miniaturas que deixa o ambiente urbano mais agradável. Ressalta ainda a presença do jardim botânico e a magnitude do palácio do presidente de província, que seria um dos melhores edifícios do Império, não deixando de destacar nos arredores da cidade as casas de campos cercadas pela vegetação de floresta, mas também composta por áreas de cultivo e criação.

Em 1848, em rápido passeio pela cidade, o botânico Henry Bates (1979, p. 12) registrou a presença de construções públicas notáveis, ao que pareciam ser as únicas em grandiosidade, a exemplo das igrejas e conventos com torres e cúpulas que despertavam o interesse dos que passavam pela cidade. Ao visitar algumas ruas próximas ao porto observava o trânsito ocasional de alguns "soldados de uniformes rotos", assim como sacerdotes, mulheres negras com potes de águas na cabeça e índios que transportavam suas crias.

Ao retomar as justificativas da necessidade de medição e demarcação de suas terras pela importância que suas posses estabeleciam com Belém, principalmente através do comércio de produtos agrícolas e extrativos, Eleutério Maximiano Terra parecia enxergar a cidade para além do centro mais urbanizado, marcado pela presença de palácios, casas residenciais e comerciais, igrejas e conventos. Os olhares de viajantes, naturalistas e observadores também não deixaram de registrar estes aspectos das cercanias de Belém.

Um caso modelar a este respeito é do viajante francês Paul Marcoy (2001, p. 285) que registrou as modificações na paisagem de Belém, após algumas caminhadas pelos arredores da cidade. No caso, depois de seguir pelas ruas "em traçados ziguezagues", comum na freguesia da Sé, alcançou o extremo Sudeste da cidade, onde registra "uma abrupta mudança de cenário". Estava agora no que identificava como "uma planície de relva ressequida e ondulante entremeada de arvoredos". Tratava-se de um espaço marcado pela presença de trilhas que acompanhavam as irregularidades do terreno, sendo que alguns 
desses caminhos perdiam-se nos matagais. Informa também que outras trilhas conduziam a belas casas construídas à sombra de mangueiras e palmeiras, assim como apresentava aspectos marcados pela presença de sítios, em que os homens eram observados em atividades de cultivo de plantas e criação de animais, típicas de áreas campestres.

Os registros das cercanias de Belém fazem referência o ano de 1847 e ao que na época se chamava de estrada de Nazaré, espaço distante do centro de comercio da cidade. Esta estrada foi descrita pelo militar Antonio Ladislau Monteiro Baena, em trabalho corográfico produzido ao longo da década de 1830, como um sítio suburbano, em que para se deslocar até o local era necessário caminhar por uma estrada plana e sem calçamento, que se iniciava no largo da Pólvora. "Orlada de um lado e de outro por matos e arbustos entrecortados por casas, tendo trezentas e noventa e seis braças de extensão", a estrada de Nazaré se apresentava como espaço característico das cercanias de Belém, em que a paisagem mesclava um ambiente de floresta como chácaras, sítios, quintas e roças espalhadas ao longo da estrada e em ramais, que circulavam o núcleo urbano. De Nazaré continuavam ainda alguns outros sítios suburbanos que conferiam à cidade uma paisagem também campestre, destacava Antonio Baena (2004, p. 211-212).

O primeiro caminho do lado direito da estrada de Nazaré era vulgarmente chamado de ramal da Pedreira, guiava para a rocinha denominada Carrapicheiro, para a de Mata-teBem, para o sitio da Pedreira, onde havia uma olaria e um engenho de descascar arroz movido por cavalos, tudo erguido nas margens do rio, que banhava as ribeiras da cidade. Para a esquerda da estrada de Nazaré registrava-se a presença do canal do Tucunduba, onde a Confraria da Misericórdia tinha uma olaria que atendia as necessidades assistenciais prestadas pela entidade através do comércio de telhas e tijolos (BAENA, 2004, p. 213).

Nas ribeiras das cercanias de Belém, ou seja, nos arredores da cidade que eram cortados por rios e igarapés, na parte Nordeste, se avistava a rocinha chamada Olaria, que estava localizada pouco abaixo do Reduto de São José, uma parte portuária da cidade. Outro exemplo é casa de campo da viúva do desembargador Pombo, localizada no lado esquerdo da entrada do igarapé do Una, em que se observavam pequenas plantações e inúmeras árvores frutíferas. Esta propriedade se posicionava em frente à olaria do comendador Rozo no lado direito do mesmo Igarapé (BAENA, 2004, p. 214), confirmando uma ocupação econômica dos arredores da cidade, principalmente quanto à presença de fazendas, olarias e engenhos. 
Ao se observar os registros sobre arredores da capital da província, os relatos de Eleutério Terra, quanto a presença de fazendeiros, sitiantes e plantadores acabam se confirmando. Este é o caso das observações de Antonio Baena que avistava ainda nas ribeiras de Belém, um sítio chamado de Penacova, que ainda em 1617 era ocupado por uma aldeia de índios chamados Una, que também dava nome ao igarapé que cortava suas terras, e onde os religiosos de Santo Antônio ergueram a sua primeira residência como o nome Hospício, que teria durado nove anos. Este local foi denominado Penacova pelo governador José de Nápoles Tello de Menezes, quando em 1782 quis avivar a antiga aldeia recebendo índios e mamelucos. No século XIX, em lugar da aldeia observava-se uma olaria e quatro palhoças de índios descendentes dos primeiros habitantes (BAENA, 2004, p. 214-215).

Subindo ao igarapé do Una, não muito distante da sua foz, se avistava as terras de um velho português chamado Danin, proprietário de uma fabrica de cerâmica. Henry Bates resolveu seguir a pé até ao local, através da mata, um percurso de quatro quilômetros e meio, embora a estrada fosse considerada quase impraticável nessa época do ano e o igarapé do Una uma via de acesso muito mais fácil. A chegada à propriedade exigia caminhar seguindo por uma estrada suburbana construída acima do nível das terras circunjacentes, que eram pantanosas. No entanto, viam-se nelas vários sítios, com arvores que chegavam a 30 metros. No caminho avistava alguns bois, pertencentes a uma propriedade situada no final "de um penumbroso caminho" (BATES, 1979, p. 31).

A propriedade do senhor Danin ficava na margem oposta do igarapé Una. Tratava-se de um prédio grande, de paredes caiadas e coberto de telhas vermelhas, construído sobre pilastras de madeira acima do chão úmido, uma características das habitações às proximidades dos rios e igarapés. O segundo pavimento era ocupado pela família, sendo que ao longo dele havia uma varanda aberta, onde trabalhavam várias pessoas de ambos os sexos e que desenvolviam diversas atividades. Na parte de baixo vários negros se ocupavam em transportar argila na cabeça, em um movimento constante de trabalho que dava ao local, aspectos de uma intensa fábrica.

Como todos os proprietários naquela província, o senhor Danin reclamava da escassez de mão-de-obra. Para tentar amenizar a dificuldade de trabalhadores em suas terras tinha se empenhado grandemente para introduzir a mão-de-obra branca, no entanto, seus esforços teriam falhado, depois de ter introduzido vários trabalhadores portugueses que contratara para os serviços na fabrica de cerâmica. Informava que todos eles os deixaram, um 
após outro, pouco depois de sua chegada. Isto era justificado pela abundancia de terras sem dono, a liberdade que imperava ali, a vida descuidosa e quase selvagem que as pessoas levavam e a facilidade com que se obtém o próprio sustento com pouco trabalho. Tudo isso teria induzido até mesmo os mais bem intencionados colono a abandonar o trabalho regular tão logo surgisse outra oportunidade, destacava Henry Bates (1979, p. 30).

Danin ainda lamentava que o auto preço dos escravos, resultado da proibição do trafico africano, havia colocado os proprietários de terras em condições que o impossibilitava a adquirir novos escravos. Isto era exemplificado quando informava "que anteriormente um escravo podia ser comprado por 120 dólares, ao passo que naquela época era difícil conseguilos por 400 dólares". Sem contar as fugas escravas que causavam prejuízos ao bom andamento do trabalho e ao bolso de seus proprietários (BATES, 1979, p. 31).

Laurindo Júnior (2012, p. 159) registra um desses casos, quando estuda a experiência do trabalho escravo em Belém nas décadas de 1870 e 1880. Trata-se de Leandro Augusto de Faria Vivas, residente no engenho Murutucú, situado nas cercanias do primeiro distrito da capital, do qual era proprietário. Ao procurar o Fórum Criminal de Belém queixava-se de Custódio Ferreira, residente no mesmo perímetro, em outra propriedade rural, chamada sítio Vidinha. Em depoimento, afirmava que no primeiro semestre de 1875 três escravos de nomes Marcelino, Izidio e Silvano haviam fugido de seu engenho com uma canoa. Ao capturar o fugitivo Marcelino, que não se sabe os meios utilizados para captura, conseguiu extrair do escravo a informação de que ele e seus companheiros tinham vendido a canoa para Custódio Ferreira, sendo que o escravo Izidio tinha se estabelecido em terras de Custódio Ferreira, onde conseguiu proteção e serviço. Para Laurindo Júnior reflete um caso em que um grupo de escravos valia de seus contatos para fugirem, tendo um deles, inclusive, optado por ficar, sob devida proteção, prestando serviço a outro proprietário. Este caso, não apenas justifica a necessidade de demanda de braços escravos para lavoura e outros serviços, como expressava o senhor Danin, como também as estratégias ilícitas para remediar a ausência de mão-de-obra escrava por alguns proprietários.

O sitio do senhor João Ferreira Touguinho denominado Santo Antonio e Almas, localizado no rio Jambuassú, termo da capital expressava bem as características dessas unidades produtoras movidas pelo trabalho escravo nas cercanias de Belém. O estudo de Barbara Palha (2011, p. 62) sobre mercado de trabalho e liberdade em Belém em tempos de escravidão, ao analisar os grandes possuidores de planteis de escravos na primeira metade 
do século XIX, informa que propriedade de João Ferreira Touguinho possuía aproximadamente três quartos de légua de terras, e meia légua de fundos, sendo ocupada por casas de vivenda e de forno com armazéns cobertas de telhas, árvores frutíferas, com mil e quinhentos pés de café. O aspecto da plantação não era do mais animador, no entanto, seiscentos pés de café em melhor estado podiam ser identificados, assim como cinqüenta pés de cacau. No sítio existiam ainda diferentes espécies de animais de criação, como touro, quatro vacas mansas, uma novilha mansa e sete ovelhas, o que dava um aspecto a esta vivenda de um espaço de moradia e produção agrícola e pastoril, comuns às propriedades rurais que se avistam nos arredores de Belém.

Seguindo os registros de uma ocupação econômica das cercanias de Belém, como apontava Eleutério Maximiano Terra, outro sítio é o de Val-de-Cãns, onde havia um engenho de açúcar, outro de descascar arroz, uma olaria, casa de recreio e capela, sendo inicialmente propriedade dos padres Mercedários, depois passou em seqüestro para o senhorio público que vendeu o sitio para particulares. Outro caso é do igarapé Araparire, destacado pela presença de vários moradores em suas margens, o que demonstrava uma distribuição da população em locais que margeavam estas fazendas, olarias e engenhos, pois muitos desses moradores se ocupavam no trabalho nestas propriedades. Exemplo disso é o sitio de Tapanã, onde havia uma olaria pequena que se estendia até o igarapé do Paracurí, com registro de alguns moradores em seu entorno que se ocupavam no fabrico de telhas e tijolos (BAENA, 2004, p. 215).

Se seguirmos observando esta região acima do sitio Tapanã, não muito longe, havia uma paragem "onde rebenta borbulhando com suave murmúrio um grande jorro de água cristalina, da qual em tempos passados se enchiam barris” (BAENA, 2004, p. 215). No caso, tratava-se de ponto de coleta natural de água em que era utilizado pelos militares, tropeiros e moradores da região, o que refletia uma cercania da cidade marcada pela circulação de pessoas e serviços, que compartilhavam espaços com as populações que ocupavam esses lugares.

A ponta do Pinheiro, também chamada de $\mathrm{Mel}$ pelos antigos moradores, na qual a corporação de Santo Elias possuiu uma fazenda denominada Nossa Senhora do Livramento pelo primeiro possuidor e doador Sebastião Gomes de Souza é outra propriedade que se destacava nas ribeiras de Belém. Correspondia uma porção de terra que se iniciava no igarapé Paracurí até a ponta do Pinheiro, entrando pelo rio Mauari, e que media 
aproximadamente uma légua. Para Antonio Baena (2004, p. 215-216) tratava-se de um local muito aprazível, sendo que na adjacência deste lugar jazia uma boca do rio Mauari, onde se observava a presença de muitos moradores que viviam basicamente da atividade da pesca.

Os casos anteriormente nos fazem dialogar com os registros do naturalista Henry Bates (1979, p. 12), ao apresentar as cercanias de Belém. Informava que o aspecto da cidade ao amanhecer "era extremamente aprazível”, registrando que a floresta primitiva cercava a cidade em todos os lados que davam para o interior, o que não significava dizer que os seus arredores estivessem ocupados apenas pela densa floresta. Observava "pitorescas chácaras espalhadas pelos seus arredores, semi ocultas pela exuberante vegetação", aspectos também observados por Antonio Baena e Eleutério Terra, como registramos anteriormente.

Importante ressaltar que Henry Bates, nesta observação, chama atenção mais diretamente para as rocinhas, ou seja, propriedades com traços rurais que estavam situadas predominantemente nos distritos menos urbanizados de Belém e comumente pertenciam às camadas mais abastadas da sociedade, como espaço de recreio e descanso aos finais de semana e feriados.

Segundo arquiteto Roberto de La Rocque Soares (1996, p. 22), estas se encontravam nos "arrabaldes da capital paraense de outrora", sobretudo em torno das estradas de Nazaré, São Jerônimo (atual avenida Governador José Malcher) e estrada de Bragança (atual Almirante Barroso). Para um registro mais social dos usos das rocinhas, as reflexões de Leandro Tocantins (1968, p. 103), parecem ser bem significativas. Para o autor, tratava-se de uma legítima propriedade rural nos arredores de Belém. Era ao mesmo tempo "campo, floresta, pomar e casa. Mas na linguagem usual significava vivenda, cercada de árvores silvestres, de fruteiras, de jardins míticos, na paz dos subúrbios”. Estas características davam a este espaço um tom campestre a estas construções. Um exemplo é a rocinha de propriedade de Bento José da Silva Santos, que também aparece como dono de outras propriedades na área central da cidade, principalmente casas comerciais. Bento Santos havia construído a sua rocinha na estrada da Independência, atual avenida Magalhães Barata, no período de 1876-79, além de possuir outras sete propriedades na mesma cercania.

As casas conhecidas como rocinhas, podem ser consideradas então, como habitações típicas da região amazônica, comum a conformação de construção que lembra aspectos do espaço rural. De acordo com Leandro Tocantins, a origem do nome 
se deve a uma expressão puramente paraense que significa a lavoura preparada, ou ainda, um referencial para aquele que vem do campo ou de áreas mais afastadas. Neste aspecto, como as rocinhas estavam localizadas em áreas mais distantes do centro de Belém, isto pode ter condicionado a construção de habitações com aspectos mais rurais. Tornava-se comum o uso da expressão "eu vim da roça" ou mesmo "eu vim do interior" em referência aos que se deslocavam da rocinha em direção à parte mais urbanizada da cidade (TOCANTINS, 1968, p. 62). Os estudos de Karol Soares (2008, p. 31) apontam que as rocinhas não significavam apenas a moradia em si, estavam associada a toda estrutura de ocupação da propriedade rural, no caso destaca-se as áreas de campo e pastagem, a floresta, o pomar e todas as áreas verdes que circulavam a moradia.

Nos arredores da cidade Henry Bates (1979, p. 12) observava não apenas as casas de campo de grupos mais abastados. A presença do que chama de "classes mais pobres" seria bem significativa. As habitações se achavam em estado bastante precário e por toda parte identificava sinais de indolência e desleixo, o que demonstrava o visível desconforto do naturalista como modo de vida da população local. Isto se materializava, portanto, na forma negativa como descrevia os locais ocupados. Informava que as casas não passavam de pequenas palhoças sem qualquer condição de conforto e tranquilidade. No caso dos quintais, que além dos fins recreativos, tornaram-se, em especial, locais destinados à criação de pequenos animais, hortaliças, à plantação de pomares, no entanto, percebia que "as estacas de madeira que cercavam os quintais, invadidos pelo mato, jaziam quebradas pelo chão, e magros porcos, cabritos e galinhas entravam e saíam pelos buracos na cerca”, o que demonstraria o descaso e pouca importância da população como os seus bens e patrimônio.

Uma ultima observação que buscamos destacar, e que faz referência as propriedades que compunham as cercanias de Belém, são feita por Henry Bates e Alfred Wallace. No caso de Bates (1979, p. 34), este fez longos registros sobre a serraria e usina de beneficiamento de arroz do Maguari, pertencente ao americano, senhor Upton. A propriedade ficava situada nas margens do riacho do Iritiri, que se comunicava com o rio Pará através de um curso de água maior, o rio Maguari. O caminho feito por Henry Bates foi por uma estrada que logo penetrava na floresta, depois, de Nazaré, de forma que em poucos minutos, aos que se aventuram seguir pela via, estavam caminhando à sombra das árvores. O trecho inicial da 
mata era constituído por capoeira, já que nos arredores da cidade a floresta primitiva tinha sido devastada, em outros tempos.

O superintendente da serraria e usina do Maguari, o senhor Leavens, que também é engenheiro prático, ao apresentar a propriedade destacava a capacidade de produção de madeiras beneficiadas no local e enviadas para o comércio no porto de Belém, expressando ainda a importância da usina no atendimento dos cultivadores de arroz da região, que tinha sua safra beneficiada e comercializada na própria usina. Sobre o cultivo e comércio do arroz, Alfred Wallace (1939, p. 32) confirma os registros de que a maior parte da produção está nas mãos dos índios e dos pequenos agricultores, que a comercializavam com os proprietários dos moinhos.

Em uma descrição do local onde estava instalada a serraria e usina do Maguari, Henry Bates (1979, p. 38) destacava que o riacho do Iritiri tinha poucos metros de largura no ponto onde ficam os moinhos, sendo que este fazia um trajeto que serpenteava certo trecho por entre paredões de mata, mas logo adiante se tornava mais largo, juntando-se ao Maguari, o que tornava a capacidade de mover os moinhos bastante reduzidas, em razão da ausência de grandes quedas d'agua na região. Há vários outros riachos ou canais que partiam dali e chegavam até lugarejos afastados ou casas isoladas, onde viviam índios e mestiços. Muitos deles faziam negócio com o senhor Leavens, vendendo suas pequenas safras de arroz ou algumas toras de madeira.

De acordo com Alfred Wallace (1939, p. 31), que como registramos, também visitou o local, a propriedade continha dois moinhos de limpar arroz e um engenho de serra. Um dos moinhos de arroz seria movido a vapor, sendo que o outro moinho e o engenho seriam movidos à água. Para isso foram represados dois ou três córregos, formando extensos lagos artificiais, visto que os rios da região não possuíam grandes corredeiras. O naturalista destaca em suas observações a importância do comércio de madeira que se estabelece na região, principalmente a maçaranduba, que são preparadas para o comércio de Belém e exportação, o que envolve não apenas quem trabalha diretamente na serraria, como ainda quem atua na extração do produto na floresta.

O Maguari é apontado como um magnífico canal, sendo que suas ramificações formam um verdadeiro labirinto num terreno que se caracterizava por sua pouca elevação, informa Henry Bates (1979, p. 38). De acordo com o naturalista, as terras são tão planas que o curso de águas locais, de curta extensão, não tem nascente, nem correm numa determinada 
direção com os rios que geralmente conhecemos. Eles ajudam a drenar o terreno, mas ao invés de uma correte continua num determinado sentido eles têm um movimento regular de fluxo e refluxo, de acordo com a maré. Este aspecto apontava para uma característica negativa das cercanias de Belém, quanto à instalação de fábricas e engenhos movidos a água, exigindo das populações locais a criação de estratégias e adaptações que pudessem superar estas dificuldades.

No caso do rio Maguari, os igarapés e os furos, ou canais, constituem para Henry Bates, uma característica da região e de boa parte das áreas que ficam no entorno da cidade de Belém. O terreno todo é coberto por uma mata impenetrável, sendo que as casas e os povoados ficam a beira d'água, e praticamente toda comunicação é feita via fluvial. Descrevendo o modo de vida local, o naturalista informa que para as pequenas excussões e para a pesca em águas paradas era usado um pequeno barco denominado "montaria". O barco não teria timão, sendo dirigido e impulsionado pelos remos. Para Bates $(1979$, p. 38) a montaria tomava ali o lugar do cavalo, do burro e do camelo de outras regiões. Além de possuir uma ou mais montarias, quase toda a família teria uma canoa maior, a quem dão o nome de "igarité", que servem para o transporte de pessoas e mercadorias, o que dava aspecto peculiar no modo de vida das populações que ocupavam as terras nos arredores da capital do Pará.

\section{ARREDORES CAMPESTRES, REAFIRMAÇÕES}

As informações de Henry Bates e Alfred Wallace sobre as populações que ocupavam as margens do rio Maguari se somam a outras observações sobre os arredores de Belém, que revelam aspectos de uma diversidade de ocupações, mas que apontam para um espaço em que as experiências de vida estão associadas a uma paisagem campestre. Estas reflexões nos remetem ao processo de medição e demarcação das posses de Eleutério Maximiano Terra, que embora não estivessem tão próximas ao núcleo mais urbanizado de Belém, legitimava seu deferimento pela importância com o comércio com a capital e o estímulo que esta ação poderia provocar no quantitativo da produção nesta propriedade e em outras posses que circundavam a cidade.

Em 12 de novembro de 1878 o presidente do Pará José Joaquim do Carmo dava por concluso os trabalhos de medição e demarcação das terras ocupadas por Eleutério Terra, informando o parecer favorável ao processo e reafirmando a necessidade de garantir a 
legalização de posses de terrenos na província como ferramenta de desenvolvimento "regular e seguro da produção". As considerações do requerente em tela, ao que se observa, parecem ter sido reaproveitadas para fundamentar uma justificativa política para o deferimento do pedido. Mais significativo ainda é observar que administração da província estava atenta para a necessidade de regular as posses de terras ocupadas nos arredores de Belém, o que evidencia a importância que esta região tinha no comércio e abastecimento da cidade.

Os registros de Eleutério Terra, portanto, muito mais que uma justificativa para regular sua propriedade, apontam para aspectos de uma cidade mergulhada em uma experiência de vida campestre que engloba as mais diversas práticas, como fazendeiros, oleiros, sitiantes, lavradores e criadores.

Figura: Planta da posse de Eleutério Maximiano Terra, 1877.

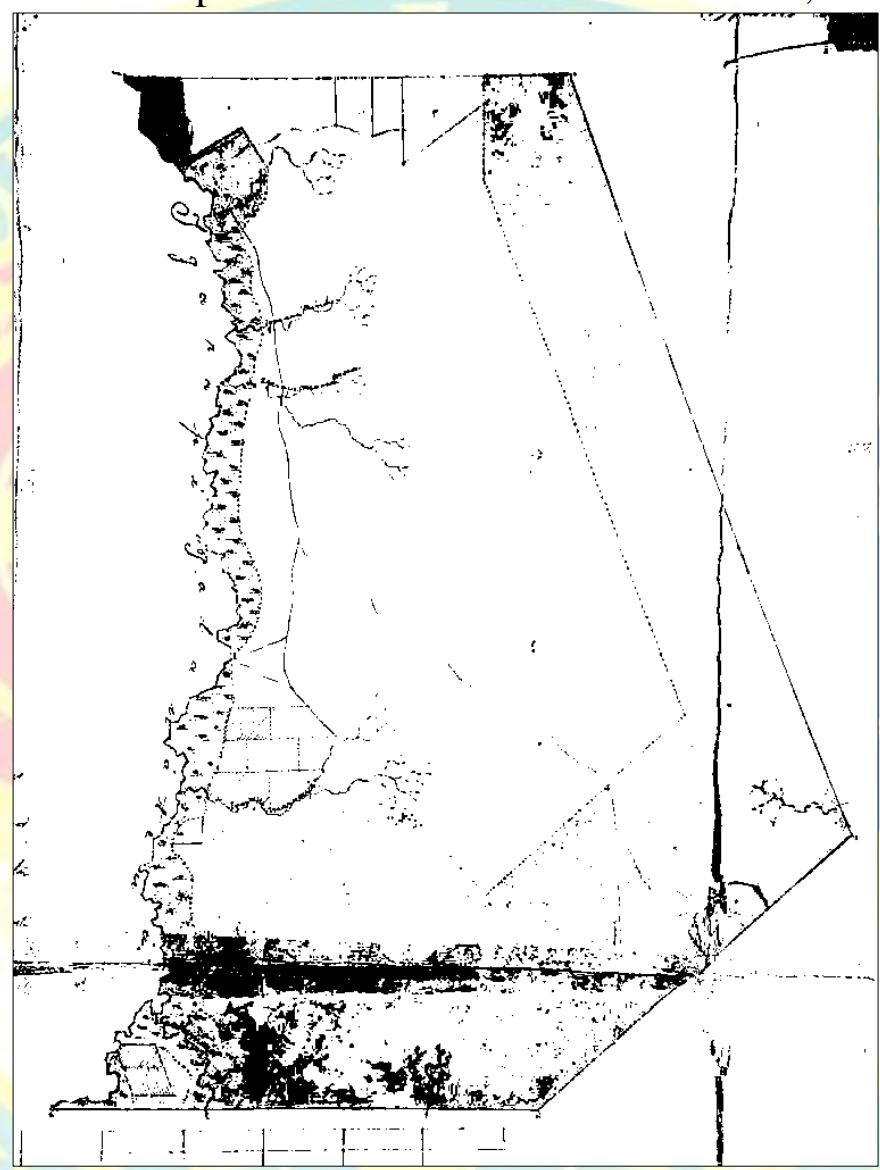

Fonte: ITERPA. Auto de medição de terra de 14 de junho de 1877. 


\section{REFERÊNCIAS BIBLIOGRÁFICAS}

AVÉ-LALLEMANT, Robert. No rio Amazonas. Belo Horizonte: Ed. Itatiaia, 1980.

BAENA, Antonio Ladislau Monteiro. Ensaio Corográfico sobre a Província do Pará. Brasília: Edições do Senado Federal, Conselho Editorial, 2004.

BATES, Henry Walter. Um Naturalista no Rio Amazonas. Belo Horizonte: Itatiaia, 1979.

CANCELA, Cristina Donza. Casamento e família em uma capital amazônica. Belém: Açai, 2011.

CRUZ, Ernesto. História de Belém. Belém: UFPA,1973.

KIDDER, Daniel Parish. Reminiscência de viagem e permanências nas províncias do Norte do Brasil. Belo Horizonte: Editora Itatiaia, 1980.

LAURINDO JUNIOR, Luiz Carlos. A cidade de Camilo: escravidão urbana em Belém do Grão-Pará (1871-1888). Dissertação (Mestrado) - Universidade Federal do Pará, IFCH, PPGHIST, Belém, 2012.

MARCOY, Paul. Viagem pelo rio Amazonas. Manaus: Editora da Universidade do Amazonas; Edições do Governo do Estado, 2001.

MARTINS, José de Souza. Subúrbio - Vida cotidiana e história no subúrbio da cidade de São Paulo: São Caetano, do fim do Império ao fim da República Velha. São Paulo: Hucitec, 2002.

PALHA, Bárbara da Fonseca. Escravidão negra em Belém: mercado, trabalho e liberdade (18101850). Dissertação (mestrado) - Universidade Federal do Pará, IFCH, PPGHIST, Belém, 2011.

SOARES, Karol Gillet. As formas de morar na Belém da Belle-Époque (1870-1910). Dissertação (Mestrado). UFPA-IFCH-PPHIST, Belém, 2008.

SOARES, Roberto de La Rocque. Vivendas rurais do Pará-rocinhas e outras (do séc. XIX ao XX). Belém: Fundação Cultural do Município de Belém, 1996.

SPIX, Johann Baptist von \& MARTIUS, Carl Friedrich Philipp von.Viagem pelo Brasil. São Paulo: Melhoramentos, Brasília: INL, 1978.

TOCANTINS, Leandro. O rio comanda a vida: uma interpretação da Amazônia. Rio de Janeiro: Record Editora, 1968.

WALLACE, Alfred. Viagens para Amazonas e rio Negro. São Paulo: Companhia Editora Nacional, 1939.

WILLIAMS, Raymond. O campo e a cidade: na história e na literatura. São Paulo: Companhia das Letras, 2011. 